\title{
Dietary intake of fluoride ashed (total fluoride) $v$. unashed (inorganic fluoride) analysis of individual foods
}

\author{
BY DONALD R. TAVES \\ Department of Pharmacology, University of Rochester School of Medicine, \\ 601 Elmwood Avenue, Rochester, New York 14642, USA
}

\section{(Received 27 August 1982 - Accepted 11 October 1982)}

\begin{abstract}
1. Fluoride content in ninety-three individual food items from a hospital in a fluoridated area was determined by ashing (total fluoride) $v$. unashing (inorganic fluoride) analysis.

2. No discrepancy between the two methods was found by food group but two dry cereals and black pepper did show significantly more fluoride after ashing. The reason for the unavailability before ashing was not determined.

3. Daily fluoride intake was estimated at $1.783 \mathrm{mg}$ which is midway between the $1 \cdot 211$ and $2 \cdot 201 \mathrm{mg}$ reported from studies in which composite diets were analysed.

4. Daily intake from food at $0.4 \mathrm{mg}$ was one-quarter of the daily total intake of $1.8 \mathrm{mg}$; a ratio consistent with those previously reported in serum, urine and bone between residents from a non-fluoridated $v$, fluoridated community.
\end{abstract}

In spite of a controversy about the intake of fluoride (Kintner, 1971; Taves, 1979), there is no reliable information on the fluoride content of individual foods. Singer et al. (1980) and SanFilippo \& Battistone (1971) have reported values for the fluoride content of composite diets rather than individual foods and while their values are more reasonable than those published by Spencer's group (Kramer et al. 1974), there are some discrepancies which need explanation. First, Singer et al. (1980) give no explanation for a daily intake which is only $55 \%$ of that reported by SanFilippo \& Battistone (1971). Second, the agreement that Singer $e t$ al. (1980) claim between ashed and unashed food analyses includes marked differences in two out of twelve food groups. In the case of green leafy vegetables, the value they report after ashing is $180 \%$ of the unashed value while in root vegetables the ashed value is $33 \%$ of the unashed value. It would be of interest to know if these discrepancies represent analytical difficulties that are inherent to the food type. A higher value with destructive analysis might reflect the presence of an organic form of fluoride which is liberated on ashing. Foods showing more fluoride on ashing would be of interest as possible sources of organic fluoride in human serum (Guy et al. 1976). The lower value on ashing might represent the loss of a volatile complex of fluoride. Information on the fluoride content of individual foods is of interest for three reasons. First, Singer et al. (1980) reported on composite food groups so the discrepancy might be considerably greater in some individual foods in a group. Second, both Singer et al. (1980) and SanFilippo \& Battistone (1971) list meat as the food group with the second highest fluoride content with values ranging from 0.22 to $1.04 \mu \mathrm{g} / \mathrm{g}(11-55 \mathrm{nmol} / \mathrm{g})$, levels considerably higher than would be expected from indirect evidence. Serum fluoride concentration in the animal is generally less than $4 \mu \mathrm{M}(0.04 \mu \mathrm{g} / \mathrm{g})$ (Taves, 1971) and, according to ${ }^{18} \mathrm{~F}$ distribution studies, fluoride concentrations in muscle would be expected to be lower than in blood (Wallace-Durbin, 1954; Hein et al. 1956; Carlson et al. 1960). Third, some fluoride balance studies in patients require the ability to prescribe a low-fluoride diet. 


\section{METHODS}

The individual foods and beverages analysed were regular hospital diets served for $6 \mathrm{~d}$ in 1977. Three food items were bought from a grocery store in 1982 for repeat analysis. The hospital is in a fluoridated area; consequently, any foods prepared with water reflect this factor. For analytical purposes, solid foods were homogenized with double-distilled and deionized water. Analysis for inorganic fluoride (unashed) was by $1 \mathrm{~d}$ diffusion at $25^{\circ}$ with hexamethyldisiloxane (HMDS) into $0.1 \mathrm{ml} 1.65 \mathrm{M}$-sodium hydroxide which was dried down and added to $0.5 \mathrm{ml} 0.66 \mathrm{M}$-acetic acid before measurement with the fluoride electrode (Waterhouse et al. 1980). Analysis for total fluoride (inorganic plus organic) was done on the same food homogenate. A $1-3 \mathrm{~g}$ portion was 'fixed' with $2.5 \mathrm{ml} 2 \mathrm{M}$-magnesium chloride in a $20 \mathrm{ml}$ platinum crucible, covered and dried overnight in a $105^{\circ}$ oven, transferred to a muffle furnace and ashed at $300^{\circ}$ for $3 \mathrm{~h}$ and at $600^{\circ}$ for a further $3 \mathrm{~h}$. Special precaution was taken to avoid contamination with trace amounts of freon which is frequently present in laboratory areas. A stream of fresh air was supplied continuously to the chamber of the muffle furnace and the door was not opened after starting the furnace until the temperature was below $200^{\circ}$. After ashing, the sample was prepared for acid-labile diffusion in the same crucible by first adding $6 \mathrm{ml}$ double-distilled and deionized water, rinsing material from the lid and side walls with $2 \mathrm{ml} 6 \mathrm{M}$-fluoride-free hydrochloric acid, depositing a Parafilm-wrapped steel ball $(10 \mathrm{~mm}$ diameter) on top of the ash, floating an inverted $12 \times 75 \mathrm{~mm}$ Falcon tube cap(Falcon, California)containing $0.1 \mathrm{ml} 1.65 \mathrm{M}-\mathrm{NaOH}$ in the centre well and covering with a $35 \times 10 \mathrm{~mm}$ Falcon tissue-culture dish bottom. The inner rim of this 'cover' had been lined with petroleum jelly and a hole had been made in the cover's surface with a soldering iron. At this point, the crucible was suspended in a cool water bath shaker, $2 \mathrm{ml} 6 \mathrm{M}-\mathrm{HCl}$ (HMDS-saturated) was added quickly through the hole in the cover, and this was immediately sealed with petroleum jelly and a Parafilm square. The shaker action causes the Parafilm ball to roll, thereby expediting the ash-dissolving process. After $1 \mathrm{~d}$ diffusion, the $\mathrm{NaOH}$ trapping-solution was treated in the identical manner to that described for the inorganic fluoride method.

Percentage recovery was determined for total fluoride with each run by ashing standards (see Table 1). No correction for incomplete recovery was applied to the sample values, i.e. the standard curve was made from standards which were neither ashed nor diffused. Analysis on the food was duplicated in alternate runs. Initially, duplication within $10 \%$ was attempted but it became apparent that homogeneity of the homogenate often was not adequate to make this requirement practical. Consequently, values for both methods reflect duplicate analysis regardless of deviation, except for the few initial samples. Condiments were from small packets, therefore duplication was by packet rather than portion.

Table 1. Percentage recovery for ashing analysis determined by adding known amounts of fluoride

\begin{tabular}{|c|c|c|c|c|}
\hline & \multirow{2}{*}{$\begin{array}{l}\text { Number of } \\
\text { samples }\end{array}$} & \multirow{2}{*}{$\begin{array}{l}\text { Amount of } \\
\text { fluoride added } \\
\text { (nmol) }\end{array}$} & \multicolumn{2}{|c|}{ Recovery $(\%)$} \\
\hline . & & & Mean & SD \\
\hline & $2^{*}$ & $2 \cdot 5$ & $71 \cdot 5$ & 13.44 \\
\hline & 14 & 5 & $85 \cdot 3$ & $13 \cdot 19$ \\
\hline & 13 & 10 & $93 \cdot 0$ & $6 \cdot 23$ \\
\hline & 8 & 25 & 97.0 & $3 \cdot 33$ \\
\hline & 3 & $50-100$ & $97 \cdot 0$ & $3 \cdot 33$ \\
\hline
\end{tabular}

* This food item was on the 2-days' menus (see p. 300). 


\section{RESULTS}

Table 2 lists ninety-three separate food items by commodity food group as described by SanFilippo \& Battistone (1971). The inorganic (unashed) or total (ashed) fluoride value for each food includes the number of analyses, mean values and standard deviations. Comparability between unashed and ashed values is given in percentage agreement calculated with 'unrounded' numbers rather than the rounded numbers given in Table 2. No systematic errors were noted by food group. In general, close agreement was found between unashed and ashed values. Of the ninety-three comparisons in Table 2 , seven show a discrepancy greater than $25 \%$ between the mean values of the 'unrounded' numbers. In two cases, the amount of fluoride involved was less than the mean $( \pm \mathrm{SD})$ ashing 'blank' of $2.6 \mathrm{nmol} \pm 0.74$, so these two discrepancies are not reliable. The difference in three comparisons (Rice Krispies ${ }^{\circledR}$, Shredded Wheat Miniatures ${ }^{\circledR}$ and ground black pepper) was more than $3 \mathrm{nmol} / \mathrm{g}$ and was statistically significant, with each showing a higher fluoride level after ashing.

Follow-up analyses were done on the three items. As the hospital food was packaged in individual serving boxes, larger boxes of each item were purchased at a store. The same pattern emerged with 552 and $827 \%$ more fluoride in Rice Krispies and $205 \%$ more in Shredded Wheat Miniatures after ashing. A regular-sized shredded wheat of another brand showed a comparability agreement of $110 \%$. Eight brands of black pepper, ranging from regular grind to whole peppercorns, were analysed and showed from 111 to $291 \%$ more fluoride after ashing with a mean $( \pm S D)$ of $210 \pm 57.5$.

Table 3 shows that the average total intake of $1.78 \mathrm{mg}$ fluoride per day falls between Singer et al.'s (1980) value of $1.21 \mathrm{mg}$ and SanFilippo \& Battistone's (1971) value of $2.20 \mathrm{mg}$. In comparison with Singer et al. (1980), the difference is due to the intake estimated for beverages $(1.38 v .0 .79)$ but in comparison with SanFilippo \& Battistone (1971), the major difference reflects disagreement between the values for dairy and meat products.

\section{DISCUSSION}

This study shows only three clear discrepancies in fluoride content of individual foods before and after ashing and these are not in the food groups with discrepancies in Singer et al.'s (1980) values. Their food group discrepancies were two to three times the $25 \%$ agreement criteria for the individual food analysis in the present study, so they were not likely to have been missed in the present study had they been real. This finding suggests that the cause of the food group discrepancy was analytical in origin and not specific to food type. However, it is clearly shown that destructive analysis liberated additional fluoride in two types of cereal and in black pepper because of the magnitude and repeatability of the difference in several samples over a 4-year period. The non-availability of the fluoride is due either to physical sequestration or organic bonding. Personal communication with the manufacturer has not disclosed a source of organic fluoride in the cereal but the most likely organic fluoride contaminant is a perfluorinated long-chain carbon compound which is not very toxic (Guy et al. 1976). Therefore, in neither case is there reason to think it is hazardous.

The fluoride values and standard deviations for meat and dairy products were considerably less than those reported by previous investigators. One explanation for the extent of variability with meat may be contamination with bone dust in the butchering process. An alternative explanation for the high values of SanFilippo \& Battistone (1971) is the possibility that their colorimetric method gave a false positive value even though the food was dried before diffusion. A direct comparison of fluoride concentration between the colorimetric and fluoride electrode methods would be needed to settle this point.

The major source of fluoride found in the present study was the grain and cereal group 
Table 2. A list by food group of inorganic and total fuoride contents of individual foods as determined by unashed $\mathrm{v}$. ashed analysis respectively of all items forming the 6-d diets from a hospital in a fluoridated area

\begin{tabular}{|c|c|c|c|c|c|c|c|}
\hline \multirow[b]{2}{*}{ Commodity group } & \multicolumn{3}{|c|}{ Inorganic F (nm/g) } & \multicolumn{3}{|c|}{ Total F (nm/g) } & \multirow{2}{*}{$\begin{array}{l}\text { Comparability (\%) } \\
\text { ashed: unashed }\end{array}$} \\
\hline & $n$ & Mean & $\mathrm{SD}$ & $n$ & Mean & SD & \\
\hline \multicolumn{8}{|l|}{ 1. Dairy products } \\
\hline Butter & 8 & 2 & $<1$ & 7 & 2 & $<1$ & 119 \\
\hline Cottage cheese & 2 & 43 & 1 & 2 & 50 & 2 & 115 \\
\hline Ice cream, vanilla & 2 & 7 & $<1$ & 2 & 7 & 2 & 97 \\
\hline Milk & 10 & 1 & $<1$ & 10 & 1 & $<1$ & 108 \\
\hline \multicolumn{8}{|l|}{ 2. Meat, fish, poultry } \\
\hline Bacon & 2 & 8 & 1 & 2 & 9 & 3 & 112 \\
\hline Beef, ground & 4 & 8 & 1 & 4 & 7 & 1 & 81 \\
\hline Beef, roast & 2 & 2 & $<1$ & 2 & 1 & 1 & 58 \\
\hline Beef, steak & 2 & 2 & $<1$ & 2 & 2 & $<1$ & 91 \\
\hline Eggs, scrambled & 6 & 3 & 1 & 6 & 4 & 1 & 113 \\
\hline Fish, broiled & 2 & 8 & $<1$ & 2 & 6 & 1 & 73 \\
\hline Fish, fried & 2 & 11 & 1 & 2 & 10 & $<1$ & 88 \\
\hline Ham, baked & 2 & 16 & 2 & 2 & 17 & 1 & 102 \\
\hline Pork, roast & 2 & 22 & 1 & 2 & 21 & $<1$ & 93 \\
\hline Sausage & 2 & 27 & 1 & 2 & 25 & 6 & 93 \\
\hline Turkey, roast & 2 & 11 & 1 & 2 & 10 & $<1$ & 95 \\
\hline Veal cutlet & 2 & 19 & $<1$ & 2 & 23 & 4 & 117 \\
\hline \multicolumn{8}{|l|}{ 3. Grain and cereal products } \\
\hline Bread, whole wheat & 2 & 15 & 6 & 2 & 17 & 3 & 111 \\
\hline Bun, hard & 2 & 21 & 1 & 2 & 23 & 1 & 106 \\
\hline Cake, chocolate & 2 & 10 & $<1$ & 2 & 13 & $<1$ & 128 \\
\hline${ }^{*}$ Cheerios $^{(1)}$ & 2 & 39 & $<1$ & 2 & 33 & 3 & 85 \\
\hline Cookie, lemon & 2 & 14 & $<1$ & 2 & 12 & 2 & 87 \\
\hline Cookie, oatmeal & 2 & 15 & 1 & 2 & 17 & 2 & 109 \\
\hline Cookie, sugar & 2 & 11 & $<1$ & 2 & 9 & $<1$ & 86 \\
\hline *Corn Flakes & 2 & 4 & $<1$ & 2 & 4 & $<1$ & 108 \\
\hline${ }^{*}$ Corn Pops ${ }^{(1)}$ & 2 & 24 & 2 & 2 & 24 & 2 & 98 \\
\hline Crackers, Ritz & 6 & 14 & 3 & 6 & 14 & 2 & 99 \\
\hline Eclair, chocolate & 2 & 7 & 1 & 2 & 8 & 1 & 108 \\
\hline *Frosted Flakes & 2 & 4 & $<1$ & 2 & 5 & $<1$ & 115 \\
\hline Hominy grits, cooked & 2 & 46 & $<1$ & 2 & 47 & 1 & 103 \\
\hline Noodles & 3 & 44 & 3 & 2 & 46 & $<1$ & 105 \\
\hline Oatmeal, cooked & 2 & 106 & 4 & 2 & 106 & 2 & 100 \\
\hline *Puffed Rice ${ }^{*}$ & 2 & 9 & $<3$ & 2 & 8 & 3 & 98 \\
\hline *Puffed Wheat ${ }^{(1)}$ & 2 & 8 & $<1$ & 2 & 10 & 1 & 122 \\
\hline * Raisin Bran & 2 & 18 & $<1$ & 2 & 18 & 3 & 97 \\
\hline Rice, cooked & 2 & 33 & 4 & 2 & 35 & 4 & 103 \\
\hline Rice Krispies ${ }^{\circledast}$ & 2 & 9 & $<1$ & 2 & 59 & 6 & 633 \\
\hline Roll, dinner & 10 & 19 & 2 & 9 & 19 & 1 & 103 \\
\hline Shredded Wheat Miniatures & 2 & 4 & $<\overline{1}$ & 2 & 8 & $<1$ & 184 \\
\hline Spaghetti and sauce & 2 & 31 & $<1$ & 2 & 33 & 5 & 107 \\
\hline Special K & 2 & 19 & 2 & 2 & 21 & 1 & 112 \\
\hline Toast & 10 & 25 & 5 & 10 & 27 & 6 & 108 \\
\hline *Wheaties ${ }^{\circledR}$ & 2 & 19 & $<1$ & 2 & 20 & $<1$ & 105 \\
\hline \multicolumn{8}{|l|}{ 4. Potatoes } \\
\hline Boiled & 2 & 26 & 2 & 2 & 25 & 1 & 96 \\
\hline Hashed brown & 2 & 23 & 3 & 2 & 23 & 4 & 102 \\
\hline Mashed & 4 & 44 & 4 & 4 & 43 & 5 & 100 \\
\hline Sweet & 2 & 11 & $<1$ & 2 & 11 & 2 & 99 \\
\hline \multicolumn{8}{|l|}{ 5. Leafy vegetables } \\
\hline Broccoli, cooked & 2 & 4 & $<1$ & 2 & 6 & $<1$ & 125 \\
\hline Cabbage, raw & 2 & 8 & $<1$ & 2 & 7 & $<1$ & 91 \\
\hline Greens, raw & 6 & 14 & 3 & 6 & 15 & 5 & 109 \\
\hline
\end{tabular}


Table 2. (cont.)

\begin{tabular}{|c|c|c|c|c|c|c|c|}
\hline \multirow[b]{2}{*}{ Commodity group } & \multicolumn{3}{|c|}{ Inorganic $F(\mathrm{~nm} / \mathrm{g})$} & \multicolumn{3}{|c|}{ Total F (nm/g) } & \multirow{2}{*}{$\begin{array}{l}\text { Comparability }(\%) \\
\text { ashed: unashed }\end{array}$} \\
\hline & $n$ & Mean & SD & $n$ & Mean & sD & \\
\hline Lettuce, raw & 3 & 7 & 1 & 3 & 6 & 1 & 82 \\
\hline Spinach, cooked & 2 & 37 & 1 & 2 & 37 & 1 & 99 \\
\hline \multicolumn{8}{|l|}{ 6. Legume vegetables } \\
\hline Green beans, cooked & 2 & 26 & $<1$ & 2 & 27 & $<1$ & 103 \\
\hline Peas, cooked & 2 & 30 & 4 & 2 & 30 & 5 & 101 \\
\hline \multicolumn{8}{|l|}{ 7. Root vegetables } \\
\hline Asparagus, cooked & 4 & 21 & 3 & 4 & 21 & 4 & 100 \\
\hline Beets, pickled & 2 & 14 & $<1$ & 2 & 14 & $<1$ & 105 \\
\hline Carrots, cooked & 2 & 25 & 2 & 2 & 24 & 1 & 96 \\
\hline \multicolumn{8}{|l|}{ 8. Garden fruits } \\
\hline Squash, cooked & 2 & 1 & $<1$ & 1 & 2 & & \\
\hline \multicolumn{8}{|l|}{ 9. Fruits } \\
\hline Apple sauce & 4 & 3 & 1 & 4 & 3 & 2 & 100 \\
\hline Cranberry sauce & 2 & 1 & $<1$ & 2 & 1 & $<1$ & 100 \\
\hline Fruit cup, canned & 2 & 4 & $<1$ & 2 & 1 & $<1$ & 95 \\
\hline Peach, canned & 2 & 4 & $<1$ & 2 & 4 & 1 & 95 \\
\hline \multicolumn{8}{|l|}{ 10. Oils and fats } \\
\hline Dressing, French & 2 & 23 & 1 & 2 & 21 & 2 & 92 \\
\hline Dressing, Lo-cal & 2 & 13 & $<1$ & 1 & 16 & 5 & 119 \\
\hline Dressing, oil and vinegar & 2 & 12 & 1 & 2 & 15 & 5 & 121 \\
\hline Margarine & 2 & 1 & 0 & 2 & 1 & $<1$ & 108 \\
\hline Tartare sauce & 2 & 16 & 1 & 2 & 15 & 3 & 96 \\
\hline \multicolumn{8}{|l|}{ 11. Sugar and adjunct } \\
\hline Ketchup & 2 & 6 & $<1$ & 2 & 7 & $<1$ & 116 \\
\hline Jam, strawberry & 2 & 10 & 1 & 2 & 8 & 1 & 80 \\
\hline Mustard & 2 & 41 & 1 & 2 & 49 & 4 & 119 \\
\hline Pepper & 8 & 18 & 5 & 8 & 28 & 5 & 158 \\
\hline Salt & 8 & 13 & 1 & 8 & 13 & 2 & 105 \\
\hline Sugar & 6 & 1 & $<1$ & 6 & 1 & $<1$ & 80 \\
\hline \multicolumn{8}{|l|}{ 12. Beverages } \\
\hline Apple juice & 2 & 5 & $<1$ & 2 & 14 & $<1$ & 91 \\
\hline Coffee & 12 & 51 & 8 & 12 & 50 & 7 & 98 \\
\hline Cranberry juice & 4 & 49 & 4 & 4 & 45 & 8 & 91 \\
\hline Grapefruit juice & 2 & 1 & $<1$ & 2 & $<1$ & $<1$ & 44 \\
\hline Grape juice & 4 & 35 & 3 & 4 & 37 & 2 & 104 \\
\hline Ginger ale & 2 & 40 & 2 & 2 & 38 & 2 & 95 \\
\hline Orange juice & 4 & 33 & 2 & 4 & 36 & 3 & 109 \\
\hline Tea & 6 & 144 & 28 & 6 & 141 & 28 & 98 \\
\hline Tomato juice & 2 & 2 & $<1$ & 2 & 2 & $<1$ & 113 \\
\hline \multicolumn{8}{|l|}{ Non-classifiable } \\
\hline Beef, tomato, pasta casserole & 2 & 35 & 1 & 2 & 38 & 11 & 88 \\
\hline Clam chowder & 2 & 19 & $<1$ & 2 & 20 & 1 & 105 \\
\hline Jellied strawberry mould & 2 & 26 & 1 & 2 & 32 & $<1$ & 120 \\
\hline Jello $^{\oplus}$, strawberry & 2 & 46 & 2 & 2 & 45 & 13 & 98 \\
\hline Macaroni and cheese & 4 & 22 & 14 & 4 & 23 & 4 & 105 \\
\hline Minestone soup & 2 & 45 & $<1$ & 2 & 41 & 1 & 91 \\
\hline Pea soup & 4 & 40 & 4 & 4 & 37 & 5 & 92 \\
\hline Pudding, bread & 2 & 39 & 1 & 2 & 37 & 1 & 94 \\
\hline Pudding, lemon & 2 & 34 & 3 & 2 & 32 & 1 & 92 \\
\hline Pudding, vanilla & 2 & 25 & $<1$ & 2 & 27 & 3 & 109 \\
\hline Turkey, broccoli, cheese bake & 2 & 15 & 1 & 2 & 15 & $<1$ & 104 \\
\hline Turkey dressing bake & 2 & 27 & 6 & 2 & 34 & 2 & 124 \\
\hline
\end{tabular}

* Additional cereals selected for analysis because of large discrepancy between inorganic and total fluoride contents found in two cereals. 
Table 3. A comparison of daily fluoride intake $(\mathrm{mg})$ as determined by individual food v. composite diet analyses

(Mean values and standard deviations for 6-d diets from a hospital in a fluoridated area (\$D given only for food group included in all $6 \mathrm{~d}$; present study) and for 2-week composite diets from four US regions from values of Singer et al. (1980) and SanFilippo \& Battistone (1971))

\begin{tabular}{|c|c|c|c|c|c|c|}
\hline \multirow[b]{3}{*}{ Commodity group } & & & \multicolumn{4}{|c|}{ Composite diet } \\
\hline & \multicolumn{2}{|c|}{$\begin{array}{l}\text { Individual foods } \\
\text { (present study) }\end{array}$} & \multicolumn{2}{|c|}{ Singer et al. (1980) } & \multicolumn{2}{|c|}{$\begin{array}{c}\text { SanFilippo \& } \\
\text { Battistone (1971) }\end{array}$} \\
\hline & Mean & SD & Mean & SD & Mean & SD \\
\hline 1. Dairy products & $0 \cdot 013$ & 0.000 & $0 \cdot 042$ & 0.007 & $0 \cdot 150$ & 0.042 \\
\hline 2. Meat, fish, poultry & $0 \cdot 044$ & 0.035 & $0 \cdot 110$ & $0 \cdot 087$ & 0.218 & $0 \cdot 102$ \\
\hline 3. Grain and cereal products & $0 \cdot 241$ & 0.153 & $0 \cdot 150$ & 0.021 & 0.208 & 0.070 \\
\hline 4. Potatoes & 0.018 & - & $0 \cdot 020$ & 0.004 & 0.048 & 0.030 \\
\hline 5. Leafy vegetables & 0.027 & 0.019 & $0 \cdot 007$ & 0.002 & 0.040 & 0.022 \\
\hline 6. Legume vegetables & 0.037 & - & 0.021 & 0.009 & 0.015 & 0.006 \\
\hline 7. Root vegetables & 0.010 & - & 0.003 & 0.001 & 0.013 & 0.005 \\
\hline 8. Garden fruits & $0 \cdot 000$ & - & 0.012 & 0.001 & 0.033 & 0.033 \\
\hline 9. Fruits & 0.006 & - & 0.018 & 0.009 & 0.040 & 0.005 \\
\hline 10. Oils and fats & 0.003 & 0.001 & 0.013 & 0.003 & 0.038 & 0.036 \\
\hline 11. Sugar and adjunct & $0 \cdot 001$ & 0.000 & 0.023 & 0.005 & 0.055 & 0.013 \\
\hline 12. Beverages & $1 \cdot 383$ & 0.041 & 0.792 & $0 \cdot 270$ & $1 \cdot 343$ & 0.080 \\
\hline Total intake & 1.783 & & $1 \cdot 211$ & & $2 \cdot 201$ & \\
\hline Total intake (minus beverages) & 0.400 & & 0.419 & & 0.858 & \\
\hline
\end{tabular}

which contributed $0.24 \mathrm{mg} / \mathrm{d}$. At least two baked goods were included in each day's diet and, as these were made locally with fluoridated water, this finding is not surprising. The large standard deviation stems from the contributions from oatmeal and pasta, both highfluoride foods and both present in the 2-days' diets. The daily intake of fluoride estimated by SanFilippo \& Battistone (1971), Singer et al. (1980) and in the present study makes much better biological sense than that published by Spencer's group (Kramer et al. 1974). The fluoride intake from food is approximately one-quarter the total intake, a value which is close to the ratio found in bone (Zipkin et al. 1958), urine (McClure \& Kinser, 1944) and serum (Taves \& Guy, 1979) fluoride concentrations between non-fluoridated community residents and those in a fluoridated community.

The fluoride contribution of $1.38 \mathrm{mg} / \mathrm{d}$ from beverages is relatively high in the present study because orange juice, coffee and two teas were included routinely in each day's diet. Drinking water was not taken into account, however, so the excellent agreement with SanFilippo \& Battistone's (1971) value may be fortuitous. While there appear to be a few foods which might contain organic fluoride, these are not staple foods which could provide an adequate explanation for the organic fluoride found in human serum after ashing.

The author would like to thank Joy Howe for technical assistance.

\section{REFERENCES}

Carlson, C. H., Singer, L. \& Armstrong, W. D. (1960). Proc. Soc. expl. Biol. Med. 103, 418.

Guy, W. S., Taves, D. R. \& Brey, W. S. Jr (1976). In Biochemistry Involving Carbon-Fluorine Bonds, p. 117

[R. Filler, editor]. Washington: American Chemical Society.

Hein, S. W., Bonner, J. F., Brudevold, F., Smith, F. A. \& Hodge H. C. (1956). Nature, Lond. $128,1295$.

Kintner, R. R. (1971). Fluoride 4, 44.

Kramer, L., Osis, D., Wiatrowski, E. \& Spencer, H. (1974). Am. J. clin. Nutr. 27, 590. 
McClure, F. J. \& Kinser, C. A. (1944). U.S. Pub. Hlth Rep. 59, 1575.

SanFilippo, F. A. \& Battistone, G. C. (1971). Clinica chim. Acta 31, 453.

Singer, L., Ophaug, R. H. \& Harland, B. F. (1980). Am. J. clin. Nutr. 33, 328.

Taves, D. R. (1971). J. Dent. Res. 40,783.

Taves, D. R. (1979). In Continuing Evaluation of the Use of Fluorides, p. 149 [E. Johansen, D. R. Taves and T. O. Olsen, editors]. Boulder, Colorado: Westview Press.

Taves, D. R. \& Guy, W. S. (1979). In Continuing Evaluation of the Use of Fluorides, p. 159 [E. Johansen, D. R. Taves and T. O. Olsen, editors]. Boulder, Colorado: Westview Press.

Wallace-Durbin, P. (1954). J. Dent. Res. 33, 789.

Waterhouse, C., Taves, D. R. \& Munzer, A. (1980). Clin. Sci. 58, 145.

Zipkin, I., McClure, F. J., Leone, N. C. \& Lee, W. A. (1958). U.S. Pub. Hlth Rep. 73, 732. 